\title{
Social and Environmental Impacts of REDD+ Strategy: An Exploratory Analysis of Nepalese Case
}

\author{
Thakur Prasad Upadhyay ${ }^{1}$, Khem Raj Bhattarai ${ }^{2}$ \\ ${ }^{1}$ School of Business and Economics, University of Troms $\varnothing$-The Arctic University of Norway, Campus Alta \\ Follumsvei 31, Alta, Norway \\ ${ }^{2}$ The National Herbarium and Plant Laboratories, Department of Plant Resources, Kathmandu, Nepal \\ Email: thakur.upadhyay@uit.no
}

Received 22 August 2014; revised 7 October 2014; accepted 20 October 2014

Copyright (C) 2014 by authors and Scientific Research Publishing Inc.

This work is licensed under the Creative Commons Attribution International License (CC BY). http://creativecommons.org/licenses/by/4.0/

(c) (i) Open Access

\begin{abstract}
This study explores the issues related to social and environmental impacts that would be generated from REDD+ (Reducing Emissions from Deforestation and Forest Degradation, and enhancing carbon storage in the forest ecosystem) intervention in Nepal. Data and other relevant information for the study have been gathered from relevant literature, stakeholder meetings, expert consultation and various websites. A SWOT (Strength, Weakness, Opportunity and Threat) analysis of REDD+ mechanism was carried out to evaluate its features. First, we reviewed and synthesized the relevant policies, plans, laws, acts, rules and regulations along with the World Bank's Safeguard Policies relevant to REDD+. The details of Strategic Environmental and Social Assessment (SESA) have been described. We present a first stage exploratory SESA framework by considering different sectors, components and institutions related to REDD+ in a holistic way. This will, in turn, form a sound basis for the detailed SESA studies in the final phase of REDD+ implementation, which later develops a comprehensive Environmental and Social Management Framework. Our analysis shows that some of the potential social and environmental impacts are overlapping, and there are gaps in terms of existing policies and institutions in order to effectively implement the REDD+ strategy in Nepal.
\end{abstract}

\section{Keywords}

Carbon Credit, Carbon Financing Transactions, Indigenous Group, Safeguard Policies, World Bank

\footnotetext{
${ }^{*}$ Corresponding author.
} 


\section{Introduction}

In view of about $20 \%$ of total greenhouse gas (GHG) emissions from deforestation and forest degradation around the globe [1], there appears to have a significant potential of reducing GHG emissions from this sector cost effectively, if programs of reducing emissions from land-use changes and forest degradation are well designed and implemented. This will, in turn, significantly contribute to mitigating the global warming and climate change as well as to the enhancement of other associated ecosystem services [2]-[4]. The existing Kyoto Protocol has no provision of paying for the carbon accumulated from the reduction of deforestation and forest degradation (DD) and carbon enhancement in the forest ecosystems of developing nations. In order to address this issue, at the $13^{\text {th }}$ conference of parties (COP13) in Bali in 2007, a broader international agreement was reached to provide the developing nations with payment for the environmental service of reducing GHG emissions through avoiding DD. This scheme was initially called REDD mechanism, and later during the COP14 in Poland in 2008 “+” was added, making the term REDD+, which meant reducing emissions from DD and carbon enhancement in forest ecosystems in developing nations [5]. In this context, the World Bank (WB) has setup the Forest Carbon Partnership Facility (FCPF) with two major objectives: 1) building capacity for formulating policy, plans and programs related to REDD+ through its technical assistance program; and 2) testing REDD+ projects with performance-based incentive payments mechanisms in some selected countries to be applicable in the much broader scale [5]. In addition to the WB led REDD+ initiatives, there are other projects going on through UN-REDD and other multinational donors support programs.

Nepal is predominantly an agrarian nation with more than $75 \%$ of total population engaged in this sector that contributes to $35 \%$ of GDP [6], and the joint production system, mostly of subsistence farming, consists of agriculture-forestry-livestock in a mosaic. The country was experiencing dual mode of land-use change and DD in the recent past. In the hilly region, the DD trend has reversed through relatively successful community forest management programs, whereas the populous low land (called Terai, Figure 2) has been facing tremendous pressure on its forests where the high valued forest stands present [7] [8]. The proposed REDD+ strategy may play an important role by providing extra monetary incentives for halting the DD and enhancing carbon stock in the forest ecosystems, mainly in the community managed forests, which have shown promising results in Nepal in the recent past. However, the major challenges to effectively implement the REDD+ strategy can be listed as: arriving at a credible estimates of national forest carbon stocks and sources of forest emissions; establishing national level reference scenarios for emissions from deforestation and forest degradation; determining the leakage and permanence of carbon sequestration through REDD+; assessing social and environmental impacts; formulating effective and equitable payment mechanisms for REDD+ carbon credits; adopting and complementing national strategies regarding DD; resolving the land tenure complexities; and designing national monitoring, reporting and verification (MRV) systems [5] [9]-[11].

Analysing and dealing with these issues forms REDD+ Readiness documents of the participating country. Nepal being a participating nation in the WB's FCPF fund for this purpose is in the process of preparing a Readiness Preparation Proposal (R-PP). A REDD+ strategy with implementation framework for formulating strategies, policies, plans and programs (PPP) in light of likely social and environmental impacts, among others components, is an important component for preparing an effective R-PP. The R-PP template has six components to be prepared, and one of the four sub-components of component 2, "Prepare the REDD+ Strategy", is Social and Environmental Impacts (2d). This Component of the R-PP document helps the REDD+ strategy in developing a work plan for how to integrate the WB's Safeguard Policies (SPs) on social and environmental impacts in the future. In this context, the study, therefore, represents an effort to undertake a preliminary Strategic Environment and Social Assessment (SESA) of REDD+ program, which have multifaceted inter-linkages both societal and ecological. The specific objectives of the study are to: present the overview of SESA process; review the existing policy and institutional framework to support REDD+ in Nepal; and analyze the first stage exploratory SESA issues, which will guide the detailed SESA with development of Environmental and Social Management Framework (ESMF) for the REDD+ strategy at the end.

The methodologies adopted for this study are desk study (detailed archival analysis), stakeholder meetings, expert consultation, qualitative and SWOT (Strength, Weakness, Opportunity and Threat) analyses. The data and information sources were basically drawn from various published documents and websites of WB, FCPF and other REDD+ related institutions. 


\section{Background: World Bank's Safeguard Policies and SESA}

The WB has been a major contributor for REDD+ Readiness in developing nations that seeks a sustainability goal for any of its development projects through SPs and SESA provisioning [5]. The main thrust for achieving this goal is to ensure that the PPPs, which have sectorial interlinkages and power relations, avoid and/or mitigate harmful effects that would be generated through such policies to society and the environment. There is a generic policy framework outlined by the WB, and this needs to be tailored with the specific needs of REDD+ Readiness in Nepalese context, where majority of population lives in rural areas and their livelihood is directly connected to complex agricultural-forestry joint production systems. Social justice and equity is another challenge that is to be dealt with for predominantly poor and diverse marginalized groups, who have traditionally been dependent in forest income and products in the rural areas of Nepal [4] [12]. Figure 1 presents the schematic view of SESA's position and its circular relations with economic, environmental, political and social dimensions at different levels of decision-making [13].

In contrast to assessing and mitigating project-level environmental (including social) impacts that is done by environmental impacts assessment (EIA) tool, the WB and other multilateral organizations are promoting SESA for REDD+ strategy in order to assess the holistic environmental and social implications of national, regional and sectorial development plans, and macroeconomic policies. SESA is an analytical and participatory approach more appropriate for the PPPs having cumulative and sector wide environmental and social implications for mainstreaming and up-streaming environmental and social issues into decision-making and implementation processes at the strategic level [13]. The overall objective of SESA is to achieve sustainable development through mainstreaming environmental and social considerations into PPPs, thereby mitigating the negative impacts and maximizing potential positive synergies in national level policy like REDD+ [13] [14]. Four key principles for SESA to be effective have been outlined by [13], which are: participatory approach during the entire decision making processes, strengthening the participating groups and social accountability, early investment in capacity building and institutional strengthening, and transparent inter-sectorial coordination. While exploring the SESA for REDD+ in Nepal these principles are to be the underlying basis to formulate the sound REDD+ strategy.

Section 3.4 of Information Memorandum of the FCPF states that any funding from WB triggers the application of SPs for mitigating the possible harm to nature and society [5]. Out of ten stipulated SPs we identified four relevant policies for REDD+ in Nepal: Environmental Assessment, Natural Habitats, Forests, Physical and Cultural Resources, Indigenous Peoples and Involuntary Resettlement [14]. These policies have respective objectives and operational principles mentioned—a sound basis for SESA for R-PP (for details about this see [14]).

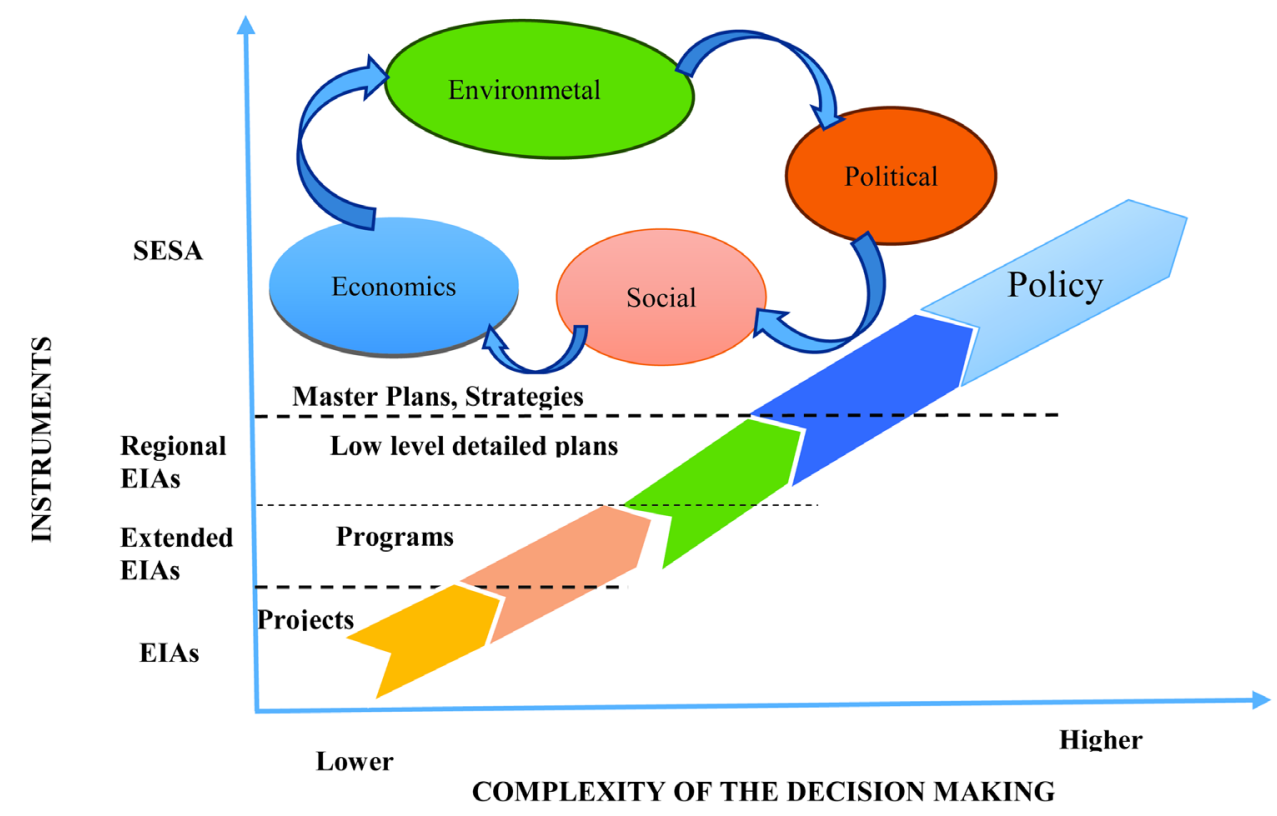

Figure 1. Schematic view of SESA in the policy and decision making framework. Source [13]. 


\section{Policy and Legal Framework}

\subsection{REDD+ Initiatives}

Cognizant of importance of REDD+ for Nepal, a R-PIN (Readiness-Plan Idea Note) has been approved in 2008 by FCPF in order to facilitate REDD+ strategy implementation in Nepal. The submitted R-PIN [15] has broadly elaborated on the extent and nature of DD, estimates of GHG emission, drivers of DD, key issues of forest laws and governance, data on forest dwellers and indigenous people, current measures of reducing DD, possible measures to address the problems of DD, descriptions of cross-sectorial policies related to REDD+, relationships between the REDD+ strategy and broader development agenda of the country, technical assistance for REDD+, processes on stakeholder consultation, challenges and opportunities of REDD+ strategy, implementation and monitoring of REDD+ strategy, additional benefits (e.g. preserving fragile mountain ecosystem, biodiversity conservation) of REDD+ strategy, areas where extra assistance from FCPF would be sought, and lists of donors assisting for REDD+ strategy development. These preliminary descriptions set the stage for further analyses of social and environmental impacts assessments of REDD+ at the R-PP stage. The central authority to implement forest related activities in Nepal is the Ministry of Forest and Soil Conservation (MoFSC), and the National Planning Commission (NPC) acts as a coordinator among various ministries in case of multi-sectorial linkages of such activities.

The external review of the R-PIN document points out some issues regarding the consultation process to forest dwellers and indigenous people (IP). It also alerts about the data set regarding DD in Nepal. The other challenges in implementing the REDD+ as pointed out by the reviewer are political instability that could further hinder law enforcement, including those associated with forest-related laws and regulations. Regarding the scope of legal framework, it suggests that the breadth and wealth of legal framework should be further crafted to create an enabling environment by which all interests (including that of IPs and vulnerable groups in the society) are accommodated. Further, it highlights the importance of CF, but mentions the problem of managing block forests in Terai and Swalikregions (Figure 2), which should be well studied before implementing the REDD+ strategy. Moreover, the higher valued-forests in these regions have been subjected to tremendous pressure both from the domestic and bordering Indian forest products markets, triggering a serious sustainable management challenges. The vague relations between the REDD+ income and broader development goals needs to be cautiously taken. Regarding the rights of IPs, it suggests following the rights-centered approach-the UN Declaration on the Rights of Indigenous Peoples and ILO 169 that Nepal has ratified. Moreover, emphasis should be placed on customary and collective rights of IPs in forest conservation and in REDD+ as well.

\subsection{Forestry Sector Policy Overview}

Nepal's forest and its associated sectorial policies are guided by various political systems ranging from autocracy to present federal democracy. Broadly, the forest policy of Nepal can be categorized into four groups: 1) Forest Policy before 1957; 2) Forest policy from 1957 to 1976; 3) Forest policy from 1977 to 1990; and 4) The modern era from 1991 to date [16]. Before the introduction of community based forest management in Nepal, the main objective of then governments was to extract revenue through "guns and fences" measures. Forest conversion to agricultural and shrub land was pervasive leading to severe deforestation and forest degradation in the past [4]. A summary of sequential development of forestry sector policies, rules, regulations and guidelines along with their relevancy to REDD+ strategy is presented in Table 1.

For the first time in the forest sector policy evolution process in 1989, Master Plan for Forestry Sector has emphasized Community Forestry (CF) programmes as one of its six primary programmes soliciting active participation of individual and communities in developing and managing forest resources to meet their basic needs [12]. The Tenth Plan (2002-2007) in its Chapter 10 has mentioned about the forestry sector objective as to provide appropriate contribution of forest sector in poverty alleviation by conservation and proper use of forest and environment [33]. Further, Poverty Reduction Strategy Paper (PRSP) [34] has clear mention of three key strategies: a) broad-based economic growth; b) social sector development; and c) targeted programmes for the backward and vulnerable groups. Singh [35] concludes that CF programmes have been useful to provide pro-poor employment opportunities in rural areas as proposed by PRSP. The three years Interim plan mentions only about the clean development mechanism to be benefited from and misses the point of REDD+. It is because REDD+ was not in the forefront at the time of writing the document and similar situation exists in all the legal, plan and 


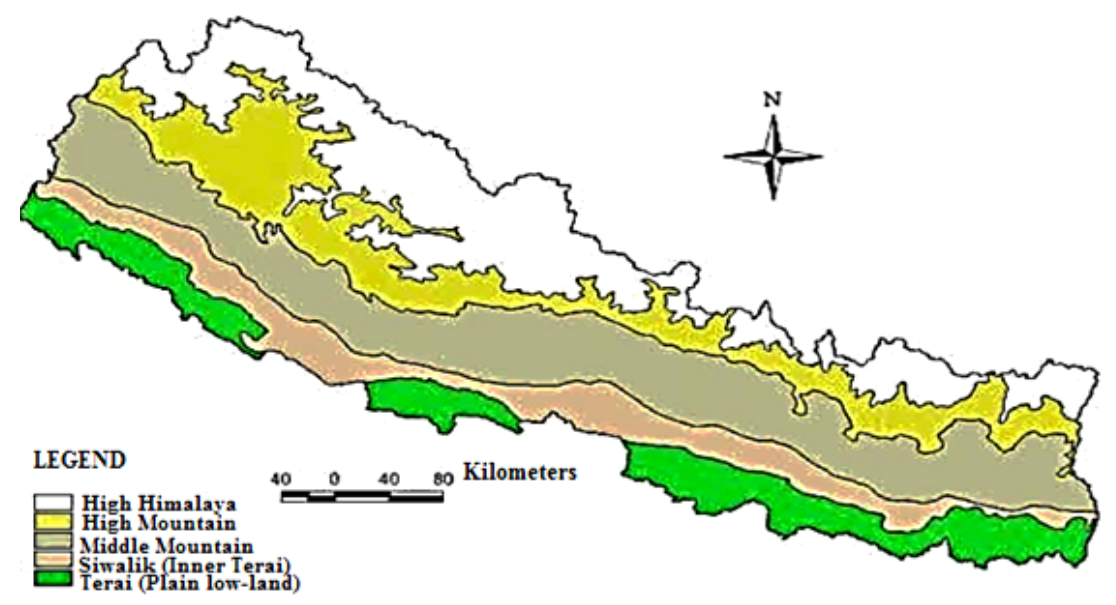

Figure 2. Physiographic map of Nepal.

Table 1. Overview of evolution of forestry sector policies and their relevancy to REDD+.

\begin{tabular}{|c|c|c|c|c|}
\hline Year & Legal documents & & Salient features & Relevancy to REDD+ \\
\hline 1957 & $\begin{array}{l}\text { Private Forest } \\
\text { Nationalization } \\
\text { Act [17] }\end{array}$ & $\begin{array}{l}0 \\
0 \\
0\end{array}$ & $\begin{array}{l}\text { Government controlled the forests } \\
\text { Created extensive forest clearing and degradation } \\
\text { Private forests converted to farmland in the } \\
\text { Terairegion }\end{array}$ & $\begin{array}{l}\text { Not much of interest for the current situation, } \\
\text { but it can give the scenario in the case of } \\
\text { property rights change from one actor to the } \\
\text { other. Can learn from the past. }\end{array}$ \\
\hline 1961 & Forest Act [18] & $\begin{array}{l}0 \\
0 \\
0\end{array}$ & $\begin{array}{l}\text { Forest land classification } \\
\text { Skill development of forestry official } \\
\text { Less emphasis to local community, "guns and } \\
\text { fences” approach }\end{array}$ & $\begin{array}{l}\text { Can learn lessons from the policy outcome, } \\
\text { which might guide for REDD+ strategy. Not } \\
\text { current information for REDD+. }\end{array}$ \\
\hline 1974 & $\begin{array}{l}\text { National Parks and } \\
\text { Wildlife } \\
\text { Conservation } \\
\text { Regulations [19] }\end{array}$ & $\begin{array}{l}\circ \\
\circ \\
\circ\end{array}$ & $\begin{array}{l}\text { Dawn of planned nature conservation initiatives } \\
\text { (helped protect forest areas) } \\
\text { Provision of hunting licenses } \\
\text { Management plans for protected areas }\end{array}$ & $\begin{array}{l}\text { REDD+ can learn the impacts of this policy on } \\
\text { carbon enhancement in the protected areas, } \\
\text { hence can be of some relevancy. }\end{array}$ \\
\hline 1976 & $\begin{array}{l}\text { National Forestry } \\
\text { Plan [20] }\end{array}$ & $\begin{array}{l}\circ \\
\circ \\
\circ\end{array}$ & $\begin{array}{l}\text { First time recognition of people's participation in } \\
\text { forest management } \\
\text { Introduction of village forest } \\
\text { Setting the stage for community forest } \\
\text { management (a success story for Nepal) }\end{array}$ & $\begin{array}{l}\text { A good start of participatory approach, and } \\
\text { REDD+ can benefit from this, but need to be } \\
\text { adapted with the new REDD+ context. }\end{array}$ \\
\hline 1988 & $\begin{array}{l}\text { National } \\
\text { Conservation } \\
\text { Strategy [21] }\end{array}$ & $\circ$ & $\begin{array}{l}\text { Conservation strategy for natural habitat of the } \\
\text { country } \\
\text { Broader perspective for higher diversity }\end{array}$ & $\begin{array}{l}\text { Can learn some lessons of strategic issues from } \\
\text { this strategy for REDD+ strategy as well. }\end{array}$ \\
\hline 1989 & $\begin{array}{l}\text { Master Plan for } \\
\text { the Forestry Sector } \\
{[12]}\end{array}$ & $\circ$ & $\begin{array}{l}\text { Beginning of program-approach in the forestry } \\
\text { sector } \\
\text { Provision of user's committees for forest } \\
\text { management } \\
\text { Detail planning and vision developed for each } \\
\text { aspects of forestry development }\end{array}$ & $\begin{array}{l}\text { First major document for the planned approach } \\
\text { for forest management for Nepal. } \\
\text { REDD+ can get much information and } \\
\text { guidelines from this and hence it is more } \\
\text { relevant to REDD+. }\end{array}$ \\
\hline 1993 & $\begin{array}{l}\text { Forest Act } \\
\text { (improved upon } \\
1961 \text { Forest act) } \\
\text { [22] }\end{array}$ & $\begin{array}{l}\circ \\
\circ \\
\circ\end{array}$ & $\begin{array}{l}\text { Moderated the extent of quasi-judicial authority } \\
\text { of forestry officials } \\
\text { Forest user groups (FUGs) empowered } \\
\text { Act oriented towards community-based } \\
\text { management. }\end{array}$ & $\begin{array}{l}\text { Can help in designing institutional mechanism } \\
\text { for REDD+ strategy and implementation. } \\
\text { REDD+ can learn from this act and extend this } \\
\text { for REDD+ context. }\end{array}$ \\
\hline 1993 & $\begin{array}{l}\text { Nepal Env. and } \\
\text { Policy Action Plan } \\
\text { [23] }\end{array}$ & $\circ$ & $\begin{array}{l}\text { Firs policy for environmental assessment for } \\
\text { development projects } \\
\text { Developed Polices related to env. sectors }\end{array}$ & $\begin{array}{l}\text { First environmental assessment policy tools for } \\
\text { Nepal, and this can give some guide for } \\
\text { REDD+. }\end{array}$ \\
\hline 1995 & $\begin{array}{l}\text { Forest Regulations } \\
\text { [24] }\end{array}$ & $\circ$ & $\begin{array}{l}\text { Legalization of the community forestry process } \\
\text { (more rights to the community) } \\
\text { Forestry staff's role changed from custodial to } \\
\text { facilitation }\end{array}$ & $\begin{array}{l}\text { Very relevant, REDD+ needs to be integrated } \\
\text { with these regulations while implementing it in } \\
\text { the field in the future. }\end{array}$ \\
\hline
\end{tabular}




\section{Continued}

\begin{tabular}{|c|c|c|c|c|}
\hline 1995 & $\begin{array}{l}\text { Agriculture } \\
\text { Perspective Plan } \\
\text { [25] }\end{array}$ & $\begin{array}{l}\circ \\
\circ\end{array}$ & $\begin{array}{l}\text { Developed a long term plan for agriculture sector } \\
\text { Accounted for the linkage with forestry }\end{array}$ & $\begin{array}{l}\text { REDD+ can learn from the interlinkages of } \\
\text { agri-forest-livestock production systems. }\end{array}$ \\
\hline 1999 & $\begin{array}{l}\text { Revision of Forest } \\
\text { Act, } 1993 \text { [26] }\end{array}$ & $\circ$ & $\begin{array}{l}\text { Developed control mechanism for violation of } \\
\text { Operational Plan by forest user groups (FUG) } \\
\text { Provision for spending the FUG fund in various } \\
\text { developmental activities }\end{array}$ & $\begin{array}{l}\text { Highly relevant to REDD+, this needs to be } \\
\text { accommodated with the current PPPs, } \\
\text { especially the payment mechanism } \\
\text { development for REDD+. }\end{array}$ \\
\hline 2000 & $\begin{array}{l}\text { 1. Revision of CF } \\
\text { Directives, 1994; } \\
\text { 2. Revision of } \\
\text { Forest Policy [27] }\end{array}$ & ○ & $\begin{array}{l}\text { Provision for compulsory inclusion of growing } \\
\text { stock of CF and annual allowable cut in } \\
\text { Operational Plan } \\
\text { Collaborative management of national forests on } \\
\text { the basis of landscape planning approach }\end{array}$ & $\begin{array}{l}\text { Important for REDD+ to get to the MRV } \\
\text { process right cost-effectively. Needs to be } \\
\text { tailed according to the need of proposed } \\
\text { REDD+. }\end{array}$ \\
\hline 2002 & $\begin{array}{l}\text { Revised Forest } \\
\text { Policy [28] }\end{array}$ & ○ & $\begin{array}{l}\text { Management of degraded and open forest areas in } \\
\text { Siwalik and Terairegions }\end{array}$ & $\begin{array}{l}\text { Important for REDD+ strategy in the Terai part } \\
\text { of the country. }\end{array}$ \\
\hline 2002 & $\begin{array}{l}\text { Nepal Biodiversity } \\
\text { Strategy [29] }\end{array}$ & ○ & $\begin{array}{l}\text { Development of Strategies to increase/conserve } \\
\text { Biodiversity } \\
\text { Linkage with forest conservation }\end{array}$ & $\begin{array}{l}\text { Little relevancy to REDD+, but the joint } \\
\text { additional ecosystem service of BD can be } \\
\text { claimed in the future. }\end{array}$ \\
\hline 2002 & $\begin{array}{l}\text { Leasehold Forest } \\
\text { Policy [30] }\end{array}$ & ○ & $\begin{array}{l}\text { Simplified the process of handing over national } \\
\text { forest to the private sector } \\
\text { Developed criteria for handing over Leasehold } \\
\text { Forests }\end{array}$ & $\begin{array}{l}\text { Relevant to REDD+ in the case of leasehold } \\
\text { forests management situation, but REDD+ } \\
\text { issues need to be included in the present } \\
\text { policy. }\end{array}$ \\
\hline 2004 & $\begin{array}{l}\text { Herbs and NTFP } \\
\text { Development } \\
\text { Policy [31] }\end{array}$ & o & $\begin{array}{l}\text { Provisions for conservation, management and } \\
\text { utilization of non-timber forest product (NTFP) } \\
\text { Linkage with forest management }\end{array}$ & $\begin{array}{l}\text { Not directly relevant, but NTFP and REDD+ } \\
\text { credit enhancement through more biomass } \\
\text { growth can be planned with right mix of } \\
\text { species in the ecosystem. }\end{array}$ \\
\hline 2008 & $\begin{array}{l}\text { Community } \\
\text { Forestry } \\
\text { Guidelines [32] }\end{array}$ & o & $\begin{array}{l}\text { Provision for including women, marginalize } \\
\text { peoples and sustainable forest products harvest }\end{array}$ & $\begin{array}{l}\text { Highly relevant to include IPs and } \\
\text { marginalized groups in the REDD+ processes. }\end{array}$ \\
\hline
\end{tabular}

strategy documents by the government of Nepal (GoN) as shown in Table 1. In terms of environmental assessment (EA) for a development project, EA guidelines 1993 was the first document that facilitated the EIA process in Nepal [23]. Later in 1997 Environmental Protection Rules began to streamline the EA issues including initial environmental examination (IEE) and EIA for the development projects of different scales [36]. Further, GoN has published Sustainable Development Agenda for Nepal in 2003 that mentions poverty reduction as main agenda with harmonization of development and environment [37].

In terms of property rights of forest land, majority of forest area belongs to the state, and those that are managed by the communities are also regulated, to some extent, by the government [16]. Therefore, the government's modus operandi regarding the management and utilization of forest products will have significant impacts on the forestry sector. On the other hand, the PPPs and their implementation depend on the type of political systems as suggested by different forest management era in Nepal (cf. Table 1). Thus, we can conclude that there is a broader vision on part of the government's plan and strategy documents for inclusive forest governance and utilization; but there is an urgent need of amendment on those documents to accommodate the present REDD+ strategy. However, due to political conflicts and poor law enforcement scenario of the existing condition in Nepal, it might be difficult to efficiently implement the REDD+ strategy in the days ahead.

\subsection{Conflict and Property Rights}

The Forest Act 1993 guarantees non-interference from the government forest office in operation of the community forestry user group (CFUG), and the management of the community forest as long as the CFUG complies with Forest Act and the Regulation and follows the CFUG's operational plan [27]. However, there is a need of amendment in it to include the REDD+ carbon credits and their ownerships as the existing plan gives the usufruct rights of CF products for five or ten years. We found some apparent overlapping of government's policies and acts over forest resources, for example in terms of property rights of forest land and authorities of government officials over the local peoples' usufruct rights. This pervasiveness of policy overlaps can hinder the REDD+ PPPs once implemented in the future. 
The CF in Nepal has evolved through a small, localised and exploratory forest management modality to a major national program involving approximately $40 \%$ of the total population over 30 years period. There is a great hope that it can play an important role in enhancing rural livelihoods and environment. However, the linearity assumptions of CF in terms of access and distribution of forest resources among various stakeholders are fraught with some questions. This is exemplified by the fact that growth of CF and the desirable social and environmental outcomes are not in balance, and there are multiple factors that shape the outcomes [38] [39]. Although about $21 \%$ of forests have been handed over to local communities as CFs, many of the crucial rights are still held by the state's agencies, and the government is inefficiently managing ca. $63 \%$ of total forest area [16]. This is especially true for those forests that are commercially valuable in Terai region. While enhancing forests' contribution to poverty reduction, weak tenure and property rights especially in the context of emerging market opportunities like REDD+ might be the major inhibiting factor for smooth operation of REDD+ strategy. This, therefore, suggests that the existing sources of conflicts in terms of rights over resources in different legal documents are to be resolved. Further, the property rights over carbon credits being generated through CF needs to be clearly established in the days ahead as distribution of REDD+ payments might create conflicts among different stakeholders once Nepal enters into REDD+ readiness.

\section{Safeguard Policies and Existing Laws}

The WB's SPs and the existing policy and legal issues discussed above is incorporated into the REDD+ policy making process by consulting the REDD-Forestry and Climate Change Cell at MoFSC. Further, feedbacks and information from two stakeholder meetings have been incorporated to this analysis. Section 3.1 of the FCPF Charter provides that "the operation of the Facility, including implementation of activities under Grant Agreements and Emission Reductions Programs, shall comply with the WB's Operational Policies and Procedures, taking into account the need for effective participation of Forest-Dependent Indigenous Peoples and Forest Dwellers in decisions that may affect them, respecting their rights under national law and applicable international obligations. Given the precise nature of the Readiness activities, the impacts will not be known until they are more fully elaborated in the Readiness Plan, the safeguards determination may need to be refined at the later stages [5]. At this stage, we have identified six SPs out of ten as relevant to R-PP for Nepal. We briefly describe them in the following sections and relate them with the existing legal and policy framework in Nepal.

\subsection{Environmental Assessment}

This SP has two major objectives: 1) To help ensure the environmental and social soundness and sustainability of investment projects; and 2) To support integration of environmental and social aspects of projects into the decision-making process. In order to materialize these objectives, WB has stipulated 11 OPs. These principles, in general, accommodate early screening of proposed project for identifying the extent and type of environmental assessment (EA), assessing potential social and environmental impacts with related legal and institutional framework, providing with alternatives of present investment, avoidance or mitigation plans of project impacts, involvement of relevant stakeholder in EA process, using independent experts in preparation of EA, linking EA process with studies of economic, financial, institutional, social and technical analyses of the project, and disclosing the draft EA in time for the information of relevant stakeholders.

In order to address this SP and OPs, the GoN has formulated Nepal Environment Policy and Action Plan (NEPAP) in 1993, and based on this document Environment Protection Act (1997) and its Regulation (1997) have been promulgated. The act and regulation has provisioned two EAs, namely, the IEE for small scale projects (final approval for the projects is done by the concerned ministry), and the EIA for large scale projects. These EA measures are meant to harmonize the development and environment for meeting the sustainability goals in the long run. However, REDD+ strategy is more than a project level task that therefore demands for detailed SESA in different phases of its development and implementation.

\subsection{Natural Habitats}

This SP intends to promote sustainable development by supporting the protection, conservation, maintenance, and rehabilitation of natural habitats and their functions. In order to materialize this objective, WB has prescribed seven OPs. These principles are related to precautionary approach to natural resources management, avoidance of conversion of critical natural habitats, cautiously go for non-critical natural habitats, emphasis on 
already cleared land for the projects, consolation of key stakeholders, providing expert help in assessing natural habitats, and disclosing the draft mitigation plan.

GoN has the following strategy, policy, plan and legal documents in relation to this SP and OPs: National Conservation Strategy (1988), Nepal Biodiversity Strategy (2002), Agro-Biodiversity Policy (2007), Buffer Zone Protection Regulations (1996), National Parks and Wildlife Protection Act (1973) and its Regulation (1974), National Wetland Policy (2003), and Herbs and NTFP Development Policy (2004).

\subsection{Forests}

This SP aims to reduce poverty, utilise forests into sustainable economic development, and protect the vital local and global environmental services and values of forests. The WB has prescribed 10 OPs in this regard. These OPs mainly relate to early screening of potential impacts of the project on forest health and quality, rights and welfare of forest dwellers, avoidance of significant land clearing project, not financing for natural forest harvesting that would involve degradation of critical habitats, support projects on non-critical habitat, supporting for certified forest industries, ensuring biodiversity restoration and conservation, giving special importance to small-scale community-level management for reducing poverty, supporting for small scale harvesting and joint forest management, emphasising forest certification systems, and disclosing the draft mitigation plan.

In order to address these issues under Forests SP, GoN have formulated and promulgated various strategies, policies, plans and programs, albeit, with varying degree of successes being recorded over time and space (cf. Table 1 and Section 3 above).

\subsection{Physical Cultural Resources}

This SP aims to assist in preserving physical cultural resources (PCR) and avoiding their destruction or damage. PCR includes resources of archaeological, paleontological, historical, architectural, and religious, aesthetic, or other cultural significance. Five OPs have been mentioned to fulfill this objective. The OPs can be summarized as using EA or equivalent process to identify and prevent or mitigate the project impacts on PCR, conduction right field survey by qualified specialists, consulting different governmental and non-governmental organizations for PCR documents and evidence to identify such sites, using "chance find" procedures for PCR management, and disclosing the mitigation plan to relevant stakeholders.

GoN in its Environment Protection Act (1997) and Environment Protection Rules (1997) have clearly mentioned about the protection of such PCR of national and international importance. Further, there is a need to improve upon this act to include PCR issue in REDD+ strategy.

\subsection{Indigenous Peoples}

This SP has an objective to design and implement projects in a way that fosters full respect for IP's dignity, human rights, and cultural uniqueness so that they: 1 ) receive culturally compatible social and economic benefits; and 2) do not suffer adverse effects during the development process. In order to address this SP, the WB has adopted nine OPs. These OPs include early screening regarding identification of IPs and their characteristics, undertaking free, prior informed consultation (PIC) with IPs to find the mitigation/compensation measures, undertaking social assessment, ensuring the IPs' involvement in project design and implementation in case of unavoidable situation to restrict from their access PAs, putting in place an action plan for the legal recognition of IP's customary rights, not undertaking commercial development of cultural resources of IPs without their FPIC, preparing IPs plan, disclosing the draft IPs plan to relevant stakeholders, and monitoring of implementation of IPs plan by expert social scientists.

This SP and the OPs are found to be poorly addressed in the existing legal policy framework in Nepal. Nonetheless, GoN has recently published a Forestry Sector Strategy for gender and social inclusion (GSI) that has identified four areas of reform: 1) Policy, rules and guidelines for sensitive sectors with respect to GSI; 2) Institutional development of good governance and GSI; 3) Budget, program and monitoring sensitive sectors with respect to GSI; and 4) Equitable access to resources, decision making and benefit sharing. It is therefore desirable to formulate policies, plans and programs based on this strategy by following the OPs of this SP to make the REDD+ strategy more effective.

While designing such policy framework effective participation of all IPs of Nepal should be mandatory. Further, the vulnerability classification of such IPs endangered, highly marginalized, marginalized and disadvan- 
taged groups in the order of decreasing scale of vulnerability and dependence in forest need to be taken into special account for REDD+ policies [4] [10].

\subsection{Involuntary Resettlement}

The main objective of this SP is to avoid or minimize involuntary resettlement and, where this is not feasible, to assist displaced persons in improving or at least restoring their livelihoods and standards of living in real terms relative to pre-displacement levels or to levels prevailing prior to the beginning of project implementation, whichever is higher. There are 12 OPs to address this SP.

In order to address these OPs under this SP, GoN has provisioned some legal and policy framework, such as in EIA guidelines for forestry sector (1995), Buffer Zone Protection Regulations (1996), Environment Protection Act (1997). To be more specific in relation to REDD+ strategy, these OPs should be duly considered in the REDD+ Readiness.

\section{Exploratory SESA}

\subsection{The SESA Framework for REDD+}

The underlying guiding principles for a complete SESA study are drawn from WB's SP and International Good Practice (IGP). Figure 3 shows the process flowchart for SESA and ESMF, where there are 12 distinct steps to follow in order develop a full SESA and ESMF framework [13]. The flowchart also mentions about the responsible entities, actions to be taken, documents to be produced and tools to be used in each of the steps. The bidirectional shaded arrows in Figure 3 show the iteration possibilities between the steps relating to the actions during the process. We base our analysis on this and adapt the concepts to Nepalese context. Based on this flowchart, Nepal falls in step 5 at present, where this exploratory SESA study has been undertaken. This is the initial SESA exercise where we conducted initial consultations to relevant stakeholders and formulated a draft SESA framework. This will, in turn, form the base for the detailed SESA and ESMF in the later phases of REDD+ implementation framework.

\subsection{Cross-Sectoral Linkages}

Since REDD+ intervention is related to various interlinked sectors, governmental organizations (GO), non-governmental organizations (NGO), community based organizations (CBO), and other stakeholders, an integrated schematic framework is required to understand the component-institutional relationships. Figure 4 shows the relationships among these variables relevant to the sectors and their corresponding components being involved in the REDD+, which are to be managed by the related GOs, NGOs and CBOs (the third column in Figure 4).

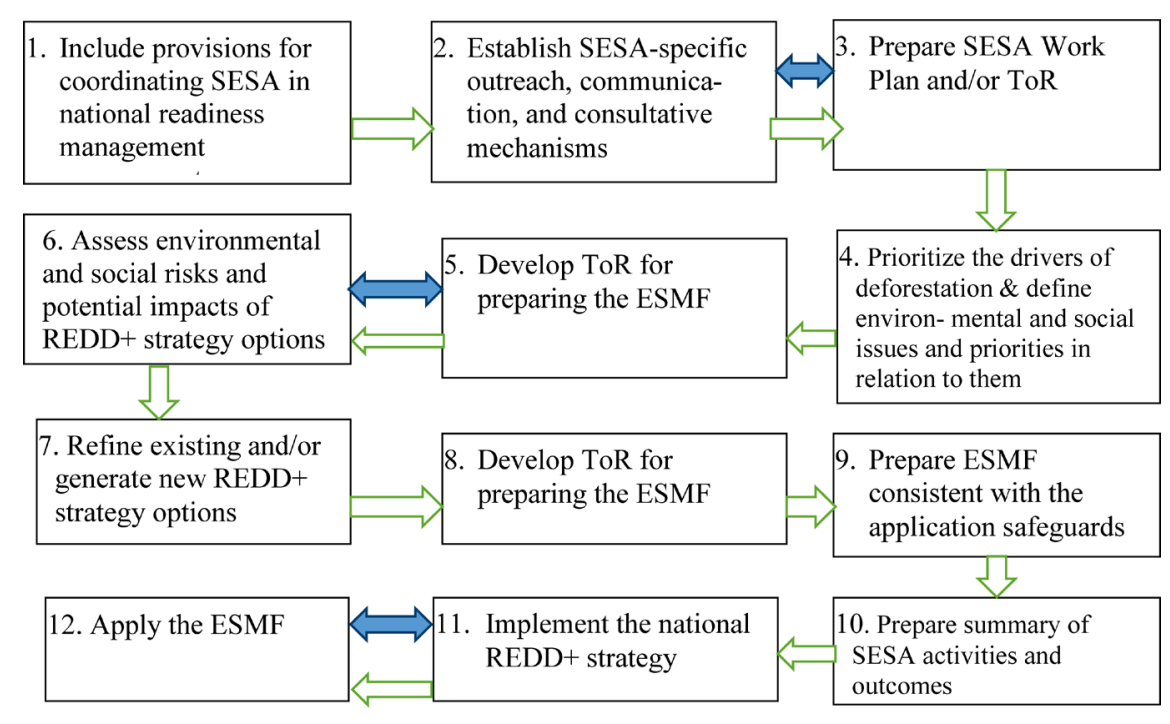

Figure 3. SESA/ESMF process flowchart (modified from [40]). 


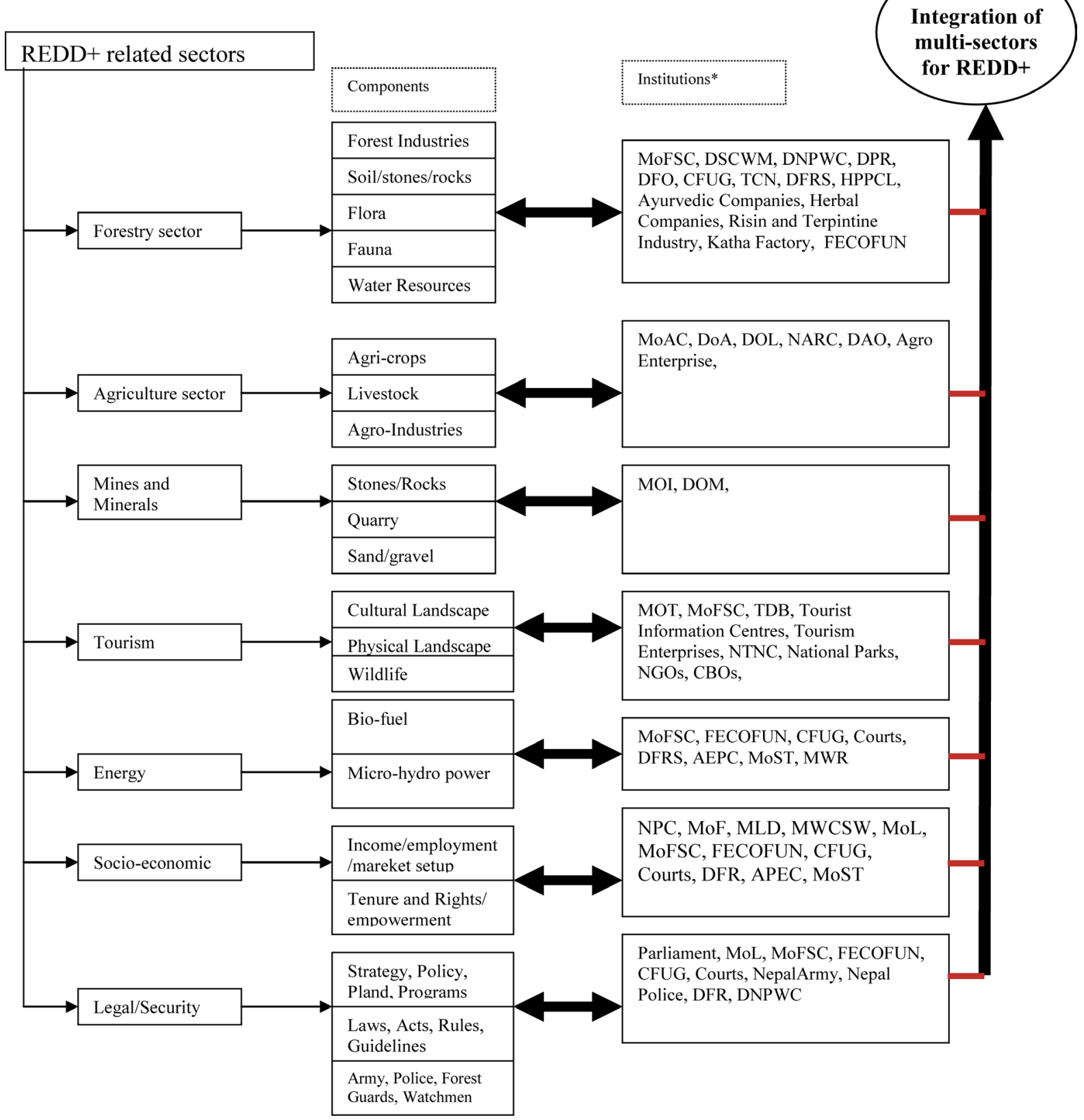

Figure 4. Integrated Framework for REDD+ related sectors, components and Institutions. *DFRS-Department of Forest Research and Survey, DSCW_-Department of Soil Conservation and Watershed, DNPWC-Department of Protected area and Wildlife Conservation, DPR—Department of Plant Resources, DFO_Department of Forest, TCN_Timber Corporation of Nepal, FECOFUN-Federation of Community Forestry Users Nepal, MoAC-Ministry of Agriculture and Cooperative, DoA-Department of Agriculture, DOL-Department of Labor, NARC—Nepal Agriculture Research Council, MOIMinistry of Industry, DOM-Department of Mines, AEPC—Alternative Energy Promotion Centre, MWR-Ministry of Water Resources, MoST-Ministry of Science and Technology, NTNC-National Trust for Nature Conservation, CBOCommunity Based Organization.

There needs to be two way interactions among the institutions and the related sectoral components to achieve the integrated REDD+ policy framework as shown by the circle at the top right position of Figure 4. This integrated framework maps the relationships among the possible sectors, components and institutions related to REDD+, giving an important overview of the institutional map for the detailed SESA and ESMF in the future. 


\subsection{Impacts Analysis}

Even though SESA does not deal with direct and indirect impacts mitigation issues [13], we found the elicitations of potential impacts due to REDD+ would prove to be a useful first step in this regard at the exploratory stage of SESA. Possible direct and indirect social and environmental impacts both positive and negative from REDD+ intervention have been analyzed. The feedback from the stakeholder meetings has provided with valuable inputs and feedbacks for the framework. As REDD+ process is still in development phase, the framework developed for impact assessment will be flexible so that future improvement possibilities through the new learned lessons over time and space can be accommodated. This framework can be further improved by consulting and discussing with concerned stakeholders in the future.

As depicted in Figure 5, we explored the initial possible products/services that might be impacted by REDD+ either in positive $(+)$ or negative $(-)$ or indeterminate $(-+)$ direction/form. We believe these variables are more or less complete in Nepalese case and some of them are affected directly and some indirectly over space and time. This forms the base for further elaboration of the impacts at different scales (both space and time) during the next phase of detailed SESA and ESMF preparation. The detailed SESA would go beyond the impacts analyses with more focus on strategic level power and institutional relationships to better handle these impacts in the future.

SWOT analysis helps identify and understand key issues affecting the given sector when new PPPs are envisaged to implement. Figure 6 summarizes the major points relating to SWOT analysis of REDD+ intervention along with its social and environmental impacts in Nepal. These identified strengths, weaknesses, opportunities and threats will prove to be useful cursor to the final SESA and ESMF documents for the REDD+.

Based on this exploratory SESA study, the success of REDD+ strategy mainly depends on: 1) effective reduction of GHG emissions from DD and more carbon sequestration in the Nepalese forests compared to the reference scenario; 2) development of cost effective and credible MRV systems; 3) equitable and efficient distribution of payments from REDD+ credits among different stakeholders including IPs, forest dwellers, marginalized groups and women; and 4) efficient governance that embraces democratic principles and includes all sections of the society in the decision making process (participatory process). The results and discussions of this exploratory study will help the analysts and concerned stakeholders for preparing the final SESA and ESMF documents. These final documents, in general, will provide the findings and recommendations that have emerged from the SESA process. The major issues to be dealt with the final SESA/ESMF reports can be listed as:

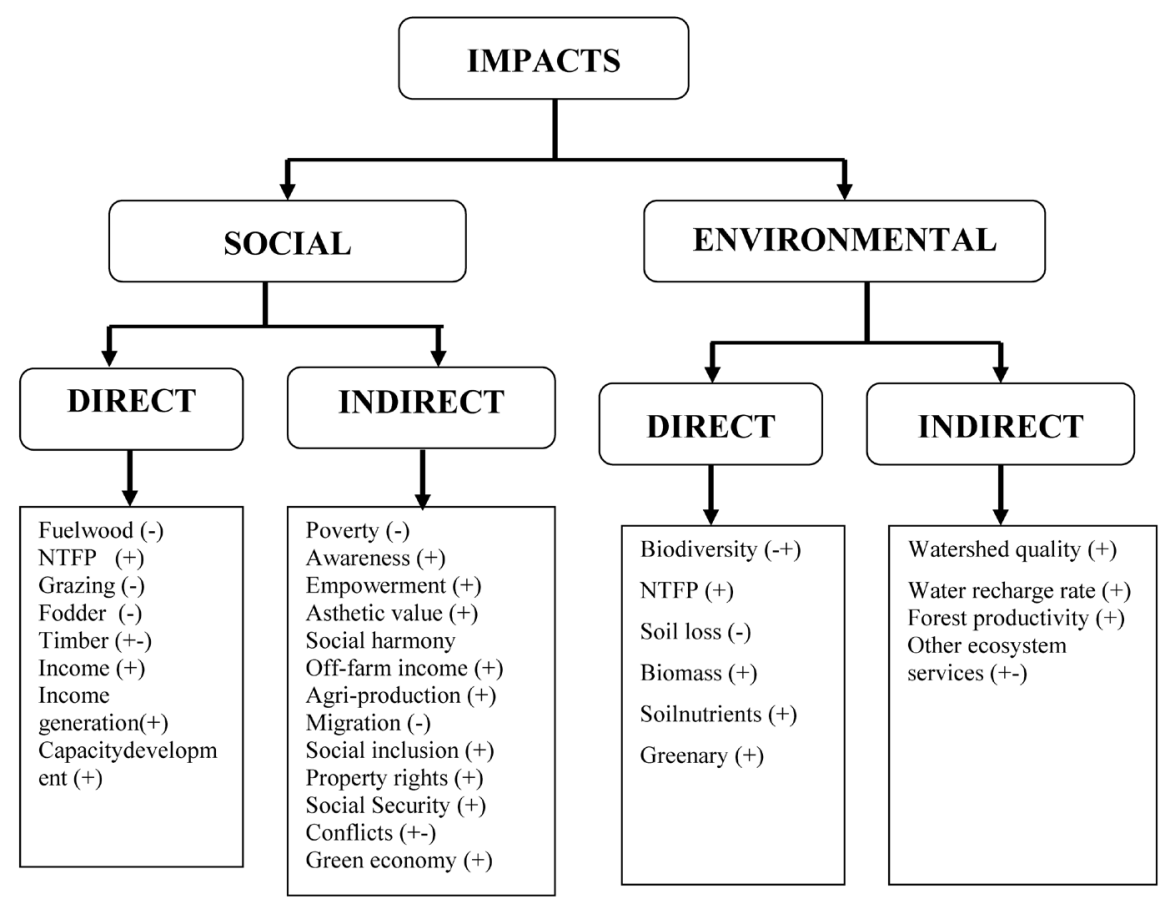

Figure 5. Possible direct and indirect impacts of REDD+ intervention. 


\begin{tabular}{|c|c|}
\hline Strengths & Weaknesses \\
\hline $\begin{array}{l}\text { Potential win-win situation both for rural } \\
\text { development and environmental conservation } \\
\text { - Well established governmental community } \\
\text { based organizations } \\
\text { - Strong commitment of government and well- } \\
\text { motivated stakeholders for REDD+ } \\
\text { - Well established networks of forest users and } \\
\text { indigenous groups } \\
\text { - Some relevant policies and legislations in } \\
\text { place } \\
\text { - Motivation of community forestry } \\
\text { management groups }\end{array}$ & $\begin{array}{l}\text { - Property rights issues and complication } \\
\text { with the community forestry expansion in } \\
\text { the Terai region } \\
\text { - Limited facilitation capacity } \\
\text { - Level of awareness- low } \\
\text { - Some conflicting interests among } \\
\text { stakeholders } \\
\text { - Poor and marginalized group yet to be } \\
\text { integrated in REDD+ strategy } \\
\text { - Issues with the coordination of various } \\
\text { diverse stakeholders }\end{array}$ \\
\hline Opportunities & Threats \\
\hline $\begin{array}{l}\text { - Green growth } \\
\text { - Harmonization with other initiatives (final } \\
\text { - Positive feedback loop to enhance other } \\
\text { ecosystem services, like biodiversity, } \\
\text { watershed improvement, etc. } \\
\text { - Funding and technical supports from different } \\
\text { sources }\end{array}$ & $\begin{array}{l}\text { - With more future cash-flow, rent seeking } \\
\text { and corruption behavior might arise } \\
\text { - Constitution making process - unclear } \\
\text { future With potential federal states } \\
\text { different policies and regulations might } \\
\text { come } \\
\text { - Potential of elite capture of the program } \\
\text { once REDD+ starts giving good income } \\
\text { streams }\end{array}$ \\
\hline
\end{tabular}

Figure 6. SWOT analysis of REDD+ SESA.

- Public Consultation and Participation Framework during REDD+ implementation,

- Policy, legal and institutional Strengthening Plan,

- ESMF applicable to REDD+ PPPs (This should include a provision for community-level monitoring and/or social auditing of the discrete investments expected to generate the largest impacts),

- Describe any weaknesses/flaws in the design adopted or methods used in the SESA process that could compromise the integrity of the findings, and

- Identify any gaps in knowledge where additional data-gathering and analysis maybe needed, and

- Capacity building plan

In order to carry out the complete SESA study and prepare the ESMF, a multi-disciplinary experts' team is required, which include professionals from Forestry, Agriculture, Economics, Ecology, Sociology Public Administration and Law.

\section{Conclusions}

We analyzed the issues on social and environmental impacts potentially being generated from REDD+ intervention in Nepal. Existing policies, plans, laws, acts, rules and regulations suggest that in order to implement REDD+ programs, significant improvements in the existing legal framework will be required. We found some pre-REDD+ policies in the forestry and other related sectors that could be used as a learning ground in order to design the effective REDD+ policies. Details of draft of the first stage SESA is described taking WB's SPs into account. This draft SESA considers different sectors, components and institutions related to REDD+ in a holistic way. We elaborated SPs and SESA more detailedly in the context of Nepalese REDD+ strategy by taking account of WBs perspective for the strategic development of big intervention projects like REDD+.

The underlying guiding principles for a complete SESA study are WB's SPs and International Good Practices. Our analysis shows that some social and environmental impacts are overlapping while some others are indeterminate giving rise to the situation of conditional outcomes of REDD+ PPPs. With the application of SPs and good practise, and the exploratory SESA as done in this study, the final SESA and ESMF will result into sustainability of the strategic development efforts like REDD+. The findings of this exploratory study will help the analysts and concerned stakeholders for preparing the final SESA and ESMF documents for REDD+ strategy for Nepal. These final documents, in general, will provide the findings and recommendations that have emerged from the SESA process. We briefly highlight the major ingredients of the final SESA and ESMF documents which could be accomplished by designating the tasks to a multi-disciplinary experts' team. 


\section{References}

[1] Gullison, R.E., Furmhoff, P.C., Canadell, J.G., Field, C.B., Nepstad, D.C., Hayhoe, K., Avissar, R., Curran, L.M., Friedlingstein, P., Jones, C.D. and Nobre, C. (2007) Tropical Forest and Climate Policy. Science, 316, 985-986.

[2] Nabuurs, G.J., Masera, O., et al., (2007) Forestry, in Climate Change 2007: Mitigation. In: Metz, B., Davidson, O.R., Bosch, P.R., Dave, R. and Meyer, L.A., Eds., Contribution of working Group III to the Fourth Assessment Report of the Intergovernmental Panel on Climate Change, Cambridge, Cambridge University Press, 541-584.

[3] Stern, N. (2007) The Economics of Climate Change: The Stern Review. Cambridge University Press, Cambridge. http://dx.doi.org/10.1017/CBO9780511817434

[4] Upadhyay, T.P., Sankhayan, P.L. and Solberg, B. (2005) A Review of Carbon Sequestration Dynamics in the Himalayan Region as a Function of Land Use Change and Forest/Soil Degradation with Special Reference to Nepal. Agriculture, Ecosystems \& Environment, 105, 449-465. http://dx.doi.org/10.1016/j.agee.2004.09.007

[5] WB (2012) The World Bank, Forest Carbon Partnership Facility Website. www.forestcarbonpartnership.org

[6] MOF (2011) Economic Survey: Fiscal Year 2010/11. Government of Nepal, Ministry of Finance, Kathmandu, Nepal.

[7] Gautam, A.P., Webb, E.L., Shivakoti, G.P. and Zoebisch M.A. (2003) Land Use Dynamics and Landscape Change Pattern in a Mountain Watershed in Nepal. Agriculture Ecosystems and Environment, 99, 83-96. http://dx.doi.org/10.1016/S0167-8809(03)00148-8

[8] Carter, J., Pokhrel, B. and Parajuli, R. (2011) Two Decades of Community Forestry in Nepal: What Have We Learned? Nepal Swiss Community Forestry Project, Kathmandu.

[9] Angelsen, A., Brockhaus, M., Kanninen, M., Sills, E., Sunderlin, W.D. and Wertz-Kanounnikoff, S., Eds. (2009) Realising REDD+: National Strategy and Policy Options. Bogor, CIFOR.

[10] Lawlor, K., Olander P.L. and Weinthal, E. (2009) Sustaining Livelihoods While Reducing Emissions from Deforestation: Options for Policymakers. NI WP 09-02. Duke University Nicholas Institute for Environmental Policy Solutions, Durham, NC.

[11] Wunder, S. (2008) Necessary Conditions for Ecosystem Service Payments. The Economics and Conservation in the Tropics: A Strategic Dialogue Conference, Moore Foundation/CSF/RFF, San Francisco, 31 January-1 February 2008. http://www.rff.org/Documents/08_Tropics_Conference/Tropics_Conference_Papers/Tropics_Conference_Wunder_PE S_markets.pdf

[12] HMGN (1989) Master Plan for Forestry Sector. Ministry of Forest and Soil Conservation, His Majesty’s Government of Nepal, Singh Durbar, Kathmandu.

[13] BIC (2014) Strategic Environmental and Social Assessments for REDD+: What Is It, Why It Matters, and How to Do It. Bank Information Centre, Washington DC. www.bicusa.org/wp-content/uploads/2013/08/Strategic-Environmental-and-Social-Assessments-for-REDD+-What-the y-are-why-they-matter-and-how-to-do-them.pdf

[14] WB (The World Bank) (2010) Safeguard Policies. www.worldbank.org/safeguards

[15] MoFSC (2008) The FCPF Readiness Plan Note (R-PIN). Ministry of Forest and Soil Conservation, Kathmandu.

[16] Kanel, K.R., Shah, S.B., Poudel, K. and Regmi, N.P. (2010) Quick Assessment of Land Use, Forest Policy and Governance. A Report Submitted to REDD-Forestry and Climate Change Cell Ministry of Forest and Soil Conservation, Kathmandu.

[17] MoFSC (1957) Private Forest Nationalization Act. Ministry of Forest and Soil Conservation, His Majesty’s Government of Nepal, Singh Durbar, Kathmandu.

[18] MoFSC (1961) Nationalization Forest Act. Ministry of Forest and Soil Conservation, His Majesty’s Government of Nepal, Kathmandu.

[19] MoFSC (1974) National Parks and Wildlife Conservation Regulation. Ministry of Forest and Soil Conservation, His Majesty's Government of Nepal, Kathmandu.

[20] MoFSC (1976) National Forestry Plan. Ministry of Forest and Soil Conservation, His Majesty’s Government of Nepal, Singh Durbar, Kathmandu.

[21] MoFSC (1988) National Conservation Strategy: Building on Success. Ministry of Forest and Soil Conservation, His Majesty's Government of Nepal, Singh Durbar, Kathmandu.

[22] MoFSC (1993) Revised National Forest Act. Ministry of Forest and Soil Conservation, His Majesty’s Government of Nepal, Singh Durbar, Kathmandu.

[23] HMGN (1993) Nepal Environmental Policy and Action Plan. His Majesty’s Government of Nepal and IUCN, Kathmandu.

[24] MoFSC (1995) National Forest Regulations. Ministry of Forest and Soil Conservation, His Majesty’s Government of 
Nepal, Singh Durbar, Kathmandu.

[25] MoA (1995) Agriculture Perspective Plan. Ministry of Agriculture, His Majesty’s Government of Nepal, Singh Durbar, Kathmandu.

[26] MoFSC (1999) Revised Forest Act 1993. Ministry of Forest and Soil Conservation, His Majesty’s Government of Nepal, Singh Durbar, Kathmandu.

[27] MoFSC (2000) Revised Forest Sector Policy. Ministry of Forest and Soil Conservation, His Majesty’s Government of Nepal, Singh Durbar, Kathmandu.

[28] MFSC (2002) Revised Forest Policy. Ministry of Forest and Soil Conservation, His Majesty’s Government of Nepal, Singh Durbar, Kathmandu.

[29] HMGN/MFSC (2002) Nepal Biodiversity Strategy. Ministry of Forest and Soil Conservation, His Majesty’s Government of Nepal, Singh Durbar, Kathmandu.

[30] MFSC (2002) Leasehold Forest Policy. Ministry of Forest and Soil Conservation, His Majesty’s Government of Nepal, Kathmandu.

[31] MFSC (2004) Herbs and Non-Timber Forest Products (NTFP) Development Policy. Ministry of Forest and Soil Conservation, His Majesty's Government of Nepal, Kathmandu.

[32] MFSC (2008) Community Forestry Guidelines. Ministry of Forest and Soil Conservation, Government of Nepal, Kathmandu.

[33] NPC (2002) The Tenth Five Year Plan (2003-2007). National Planning Commission, His Majesty’s Government of Nepal, Kathmandu.

[34] NPC (2003) Poverty Reduction Strategy Paper. National Planning Commission (NPC), Kathmandu.

[35] Singh, B.K. (2004) Complementary Pro-Poor Programme in Community and Leasehold Forestry. Proceedings of the Fourth National Workshop on Community Forestry, Kathmandu, 4-6 August 2004, 195-198.

[36] MOPE (1997) Environment Protection Act, 1996 and Environment Protection Regulations, 1997. Ministry of Population and Environment, HMGN, Kathmandu.

[37] MOPE (2003) Sustainable Development Agenda for Nepal. Ministry of Population and Environment, His Majesty’s Government of Nepal, Kathmandu.

[38] Adhikari, B., Di Falco, S. and Lovett, J.C. (2004) Household Characteristics and Forest Dependency: Evidence from Common Property Forest Management in Nepal. Ecological Economics, 48, 245-257. http://dx.doi.org/10.1016/j.ecolecon.2003.08.008

[39] Acharya, K.P. (2003) Conserving Biodiversity and Improving Livelihoods: The Case of Community Forestry in Nepal. The International Conference on Rural Livelihoods, Forests and Biodiversity, Bonn, 19-23 May 2003.

[40] BIC (2013) SESA/ESMF Process Flowchart. Bank Information Centre, Washington DC. http://www.bicusa.org/wp-content/uploads/2013/12/SESA-ESMF-Process-Flowchart.pdf 
Scientific Research Publishing (SCIRP) is one of the largest Open Access journal publishers. It is currently publishing more than 200 open access, online, peer-reviewed journals covering a wide range of academic disciplines. SCIRP serves the worldwide academic communities and contributes to the progress and application of science with its publication.

Other selected journals from SCIRP are listed as below. Submit your manuscript to us via either submit@scirp.org or Online Submission Portal.
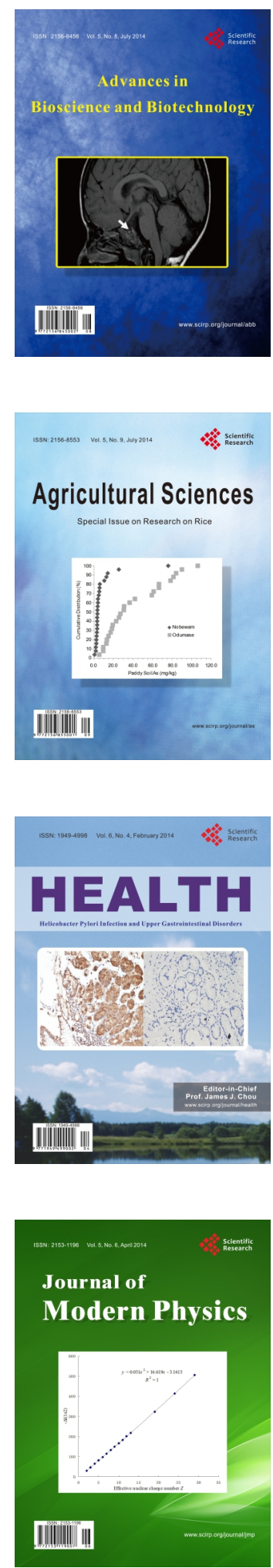
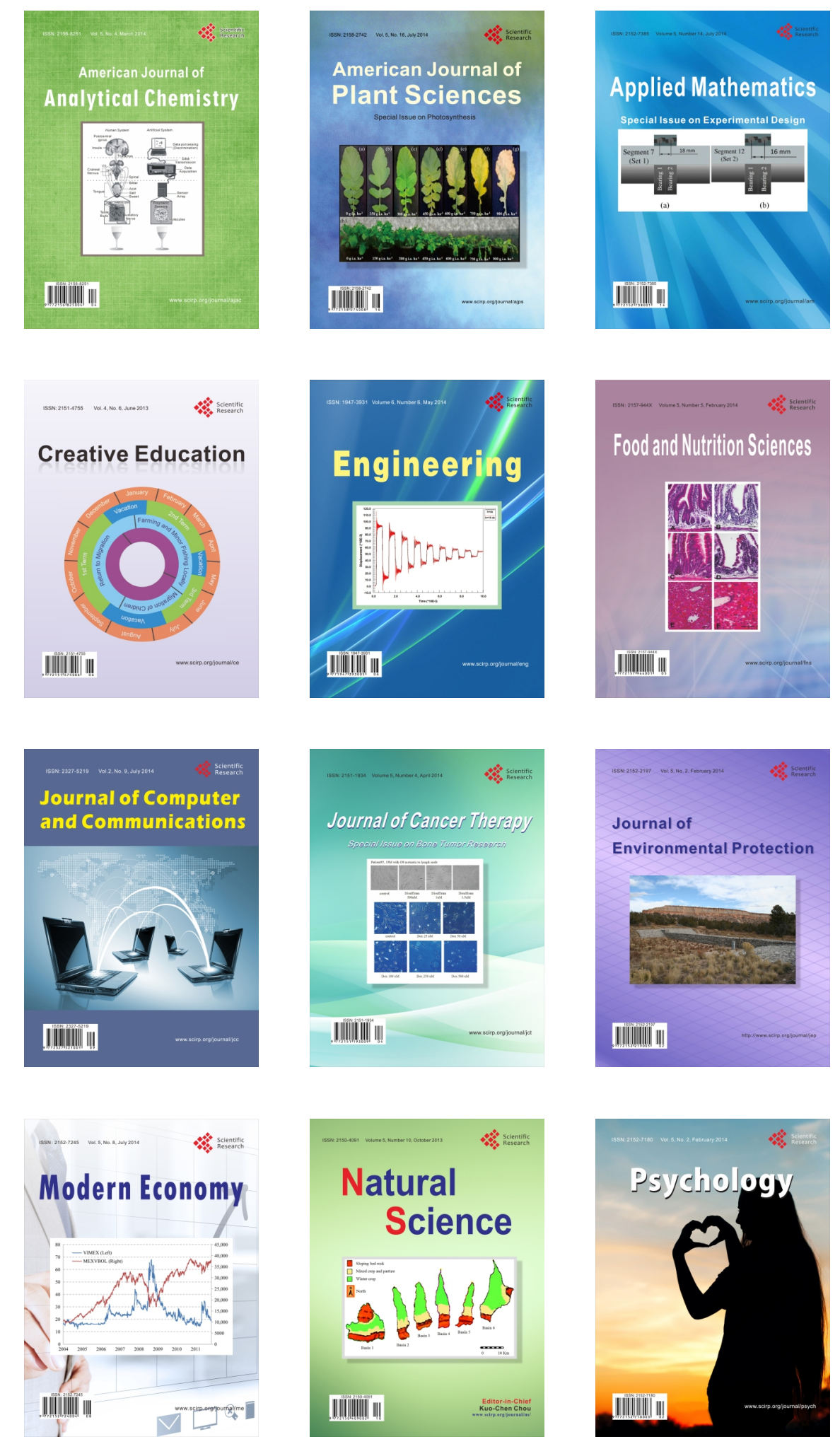